\title{
RANCANGAN SISTEM DATA LOGGER UNTUK MENDETEKSI GAS CARBON MONOKSIDA (CO) DAN NITROGEN MONOKSIDA (NO) BERBASIS MIKROKONTROLER
}

\author{
${ }^{1)}$ Muhammad Sahri, ${ }^{2)}$ Misbah, ${ }^{3)}$ Hendra Ari Winarno, \\ ${ }^{1,2,3)}$ Jurusan Teknik Elektro, Fakultas Teknik, Universitas Muhammadiyah Gresik \\ JL. Sumatra No 101, Gresik 61121, Jawa Timur \\ Email : msyahri75@yahoo.co.id ${ }^{1)}$,misbah.grs@gmail.com ${ }^{2)}$, hendra.umg@gmail.com ${ }^{3)}$
}

\begin{abstract}
Abstrak
Gas merupakan suatu besaran yang mudah berubah-ubah. Oleh karena itu pengukuran dan pengamatan yang berulang-ulang yang hasilnya disimpan untuk dikaji lebih lanjut perlu dilakukan. Pendataan dan pengamatan tersebut masih banyak yang dilakukan secara manual yang kenyataannya memiliki kelemahan-kelemahan diantaranya adalah banyaknya waktu yang diperlukan untuk melakukan pendataan dan pengamatan, kepresisian hasil pendataan, dan teknik pengambilan data masih bisa diragukan.

Sebagai jalan keluar dari permasalahan tersebut maka dibuat data logger Gas CO dan NO yang dapat menyimpan data secara otomatis agar dapat mengetahui perkembangan polutan udara. Sistem data logger Gas CO dan NO ini menggunakan sensor Gas TGS 2201 yang akan aktif bila terdapat gas CO dan NO di lingkungan tertentu. RTC (Real Time Clock) untuk menentukan waktu terdeteksinya gas CO dan NO. Memori SD/MMC (Multimedia Card) untuk menyimpan data yang di hasilkan oleh sensor Gas. Data yang tersimpan didalam SD Card dapat dibaca pada komputer menggunakan card reder dengan output excel.

Berdasarkan penelitian yang dilakukan sistem data logger berguna menyimpan data RTC dan gas CO,NO. Dimana kapasitas memori SD Card 8GB, sebagai penyimpan data 70KB perhari, interval pengambilan data 1 menit sekali yang dapat digunakan selama 120 hari.
\end{abstract}

Kata kunci: Datalogger, SD Card, gas sensor TGS2201,RTC

\section{Latar Belakang}

Pertumbuhan kendaraan bermotor di Indonesia saat ini telah mencapai lebih dari $10 \%$ per tahun menjadi faktor dominan penyebab utama naiknya pencemaran udara. Kondisi ini di perburuk dengan angka pertumbuhan jalan yang tidak sebanding dengan 
pertumbuhan kendaraan bermotor yang hanya $2 \%$ per tahun, semakin memperburuk kondisi udara di berbagai kota. Diantara sumber polutan emisi gas buang yang dikeluarkan dari sumber kendaraan bermotor, persentasi emisi gas buang $\mathrm{CO}$ (Carbon Monoksida) dan NO (Nitrogen Monoksida) cukup signifikan mencapai 60\% termasuk jenis gas yang sangat berbahaya karena bisa mengakibatkan kematian bagi yang menghirupnya. Untuk mengetahui keadaan gas dari suatu lingkungan dapat dilakukan dengan pengukuran secara langsung menggunakan suatu alat ukur gas $\mathrm{CO}$ (Carbon Monoksida) dan NO (Nitrogen Monoksida). [3]

Banyak Alat ukur emisi gas buang kendaraan bermotor yang di pasaran dengan harga yang bervariasi. Alat tersebut memiliki keunggulan masing-masing dan keakuratan, Alat pendeteksi emisi gas buang kendaraan bermotor yang pernah dibuat mahasiswa S1. Alat ini mampu menguji gas beracun yaitu, NO (Nitrogen Monoksida), CO (Carbon Monoksida), $\mathrm{HC}$ (Hidrokarbon), dan $\mathrm{H}_{2}$ (Hidrogen). Dengan nilai ketelitian $90.62 \%$ dan dapat menampilkan hasil yang di deteksi sensor gas ke LCD ini menunjukan penelitian yang di lalukan di dekat knalpot kendaraan bermotor untuk menghasilkn seberapa besar gas CO dan NO yang di deteksi oleh sensor sudah mendekati alat yang di buat industri. [7]

Pada penelitian sebelumnya oleh Hilmi Yulianto (2013) itu hanya sebatas mengetahui gas buang kendaraan bermotor. Oleh karena itu dalam skripsi ini akan dibuat sistem pencatatan dan perekaman gas polutan mengunakan data logger berbasis mikrokontroler. Yang mana penelitian ini dilakukan di suatu daerah untuk mengetahui tingkat polusi yang setiap hari beruba-ubah dan mempunyai system perekaman data yang di gunakan sebgai perbandingan. Sistem keseluruhan Data Logger gas CO dan NO terdiri dari sensor gas TGS 2201, RTC (Real Time Clock), Memori Eksternal dan LCD (liquid crystal display).

\section{Sensor PIR ( Passive Infra Red )}

Sensor gas TGS2201 merupakan salah satu sensor yang dipakai dalamnpenelitian ini. Sensor ini adalah sebuah sensor kimia atau sensor gas yang mempunyai nilai resistansi (Rs) yang akan berubah bila terkena emisi gas buangkendaraan bermotor di udara. Sensor gas TGS memiliki keistimewaan, karena dapat digunakan untuk mendeteksi emisi gas buang dari bahan bakar bensin dan solar.

Alat ini memiliki sensitivitas yang tinggi terhadap emisi gas buang berupa gas $\mathrm{CO}, \mathrm{NO}, \mathrm{NO}_{2}, \mathrm{H}_{2}$, dan senyawa hidrokarbon. Jika sensor tersebut mendeteksi keberadaan salah satu komponen gas diudara, misalnya gas CO dengan tingkat konsentrasi tertentu maka resistansi elektrik sensor tersebut akan menurun. Sehingga akan menyebabkan tegangan yang dihasilkan oleh output sensor akan semakin besar. Selain itu, sensor TGS juga mempunyai sebuah pemanas (heater) yang digunakan untuk membersihkan ruangan sensor dari kontaminasi udara luar, agar sensor dapat bekerja kembali secara efektif. Secara umum bentuk dari sensor gas Gas CO jenis TGS dapat dilihat pada gambar 1.berikut ini:

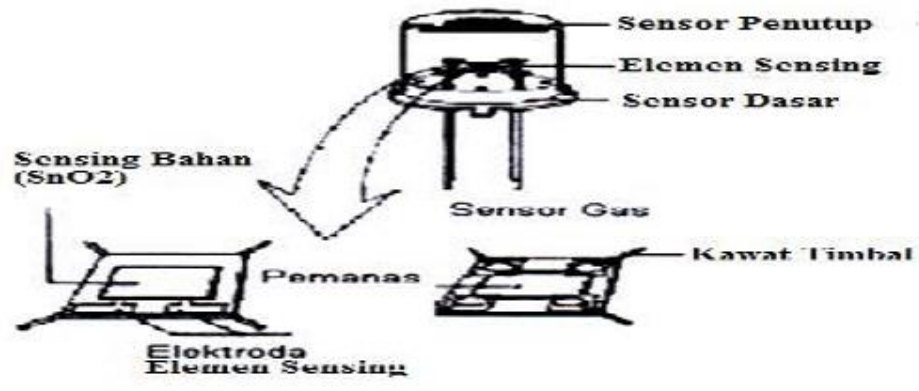




\section{Gambar 1. Ilustrasi gambar komponen sensor TGS}

Untuk mengukur karakteristik sensitivitas dari gas buang kendara bermotor, semua data diuji pada kondisi standar. Sumbu Y axis menunjukk rasio resistansi sensor (Rs/Ro), dengan ketentuan :

* Rs = sensor perlawanan dari gas dengan berbagai konsentrasi.

$*$ Ro $=$ resistansi sensor dalam udara bersih

Berikut ini dapat dilihat gambar 2. karakteristik sensitivitas dari emisi gas buang dari kendaraan bermotor berbahan bakar bensin.

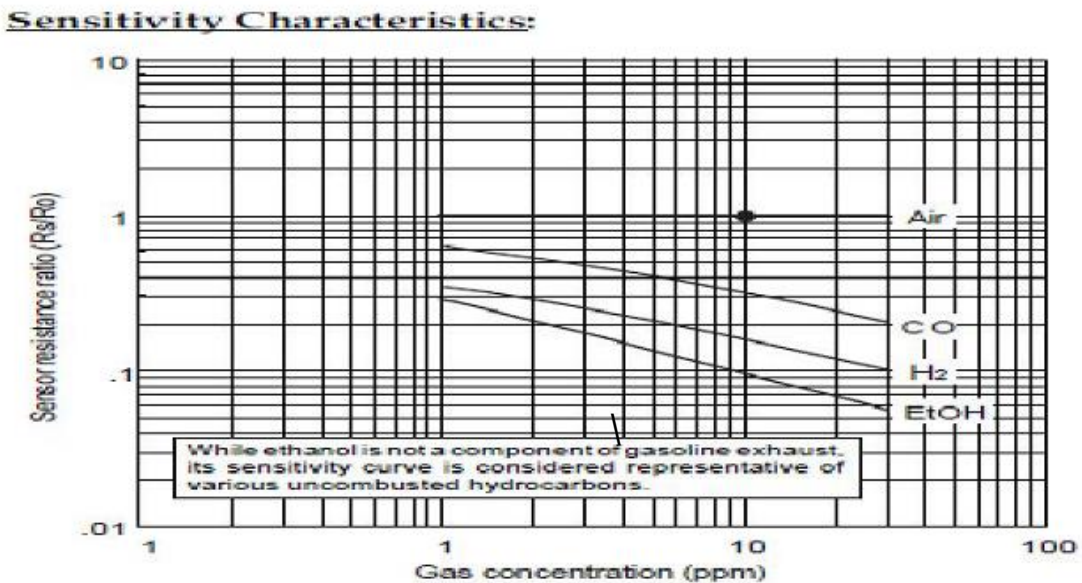

Gambar 2. Karakteristik Sensifisitas dari Emisi Gas Berbahan Bakar Bensin

Berikut ini dapat dilihat gambar 3. karakteristik sensitivitas dari emisi gas buang kendaraan bermotor berbahan bakar solar.

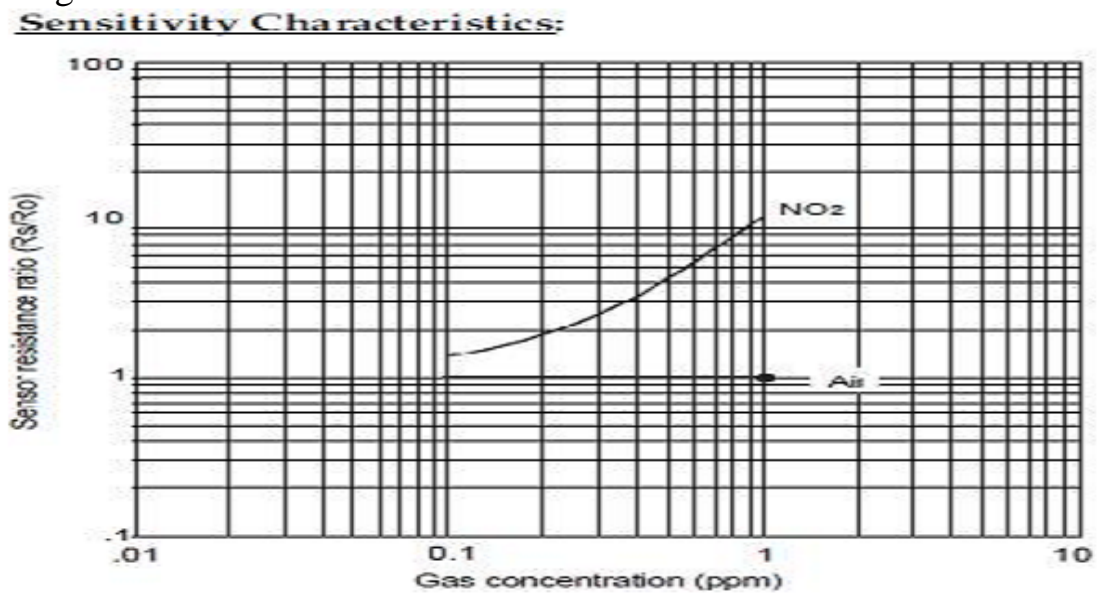

Gambar 3. Karakteristik Sensifisitas dari Emisi Gas Berbahan Bakar Solar

\subsection{Mengukur Circuit Sensor TGS2201}

Sensor memerlukan dua tegangan masukan: pemanas tegangan $\left(\mathrm{V}_{\mathrm{H}}\right)$ dan tegangan rangkaian $\left(\mathrm{V}_{\mathrm{C}}\right)$. Tegangan pemanas $\left(\mathrm{V}_{\mathrm{H}}\right)$ diterapkan ke pemanas terintegrasi untuk mempertahankan elemen penginderaan pada suhu tertentu yang optimal untuk mensensor. $\mathrm{V}_{\mathrm{C}}$ diterapkan untuk mengukur tegangan output $\mathrm{VR}_{\mathrm{L} 1}$ dan $\mathrm{VR}_{\mathrm{L} 2}$ di $\mathrm{R}_{\mathrm{L} 1}$ dan $R_{L 2}$ masing-masing. Setiap beban resistor dihubungkan secara seri ke elemen 
sensing yang bersesuaian. Catu daya umum sirkuit dapat digunakan untuk kedua $\mathrm{V}_{\mathrm{C}}$ dan $\mathrm{V}_{\mathrm{H}}$ untuk memenuhi Sensor kebutuhan listrik. Itu nilai resistor beban $\left(\mathrm{R}_{\mathrm{L}}\right)$ harus dipilih untuk mengoptimalkan alarmambang nilai, menjaga disipasi daya $\left(\mathrm{P}_{\mathrm{S}}\right)$ dari semikonduktor di bawah batas $15 \mathrm{~mW}$. Disipasi daya $\left(\mathrm{P}_{\mathrm{S}}\right)$ akan tertinggi ketika nilai Rs sama dengan $R_{L}$ pemaparan pada gas. Berikut ini tabel 2.4. spesifikasi sensor TGS 2201.

Tabel 2.4. Spesifikasi Sensor TGS 2201

\begin{tabular}{|c|c|c|c|c|}
\hline \multicolumn{3}{|c|}{ Model number } & \multicolumn{2}{|c|}{ TGS 2201} \\
\hline \multicolumn{3}{|c|}{ Sensing element type } & \multicolumn{2}{|c|}{ s2 } \\
\hline \multicolumn{3}{|c|}{ Standard package } & \multicolumn{2}{|c|}{ Plastic (P3) } \\
\hline \multicolumn{3}{|c|}{ Target gases } & $\begin{array}{l}\text { Diesel exhaust } \\
\text { (NO, NOz) }\end{array}$ & $\begin{array}{l}\text { Gasoline exhaust } \\
(\mathrm{CO}, 1|z, 1| C)\end{array}$ \\
\hline \multicolumn{3}{|c|}{ Typical detection range } & $0.1 \sim 10 \mathrm{ppm}$ & 10 1,000ppm \\
\hline \multirow{3}{*}{$\begin{array}{l}\text { Standard circuil } \\
\text { conditions }\end{array}$} & Heater voltage & $V_{H}$ & \multicolumn{2}{|c|}{$7.0 \pm 0.35 \vee D C$} \\
\hline & Circuit voltage & $v_{0}$ & \multicolumn{2}{|c|}{ 15. oV DC Max., $\Gamma_{s} \leq 15 \mathrm{~mW}$} \\
\hline & Luad Iesistance & RL & \multicolumn{2}{|c|}{ Vatiable, PS S $15 \mathrm{H} W$} \\
\hline \multirow{5}{*}{$\begin{array}{c}\text { Electrical } \\
\text { characteristics } \\
\text { under standard test } \\
\text { conditions }\end{array}$} & $\begin{array}{l}\text { Heater } \\
\text { resistance }\end{array}$ & $\mathrm{RH}_{\mathrm{H}}$ & \multicolumn{2}{|c|}{$65 \pm 6 \Omega 2$ at room temp. } \\
\hline & Heater current & $\mathrm{IH}$ & \multicolumn{2}{|c|}{$72 \mathrm{~mA}$} \\
\hline & $\begin{array}{l}\text { Heater powcr } \\
\text { consumption }\end{array}$ & $P_{11}$ & \multicolumn{2}{|c|}{$\begin{array}{c}505 \mathrm{~mW} \\
\mathrm{~V}_{H}=7.0 \mathrm{VDC}\end{array}$} \\
\hline & $\begin{array}{l}\text { Sensor } \\
\text { resistance }\end{array}$ & Rs & $250 \mathrm{k} \Omega$ in dir $^{--}$ & $25 \mathrm{k} \Omega$ in 1 dir - \\
\hline & \multicolumn{2}{|c|}{$\begin{array}{l}\text { Sensitivity } \\
\text { (cnange ratio or Rs) }\end{array}$} & 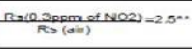 & $\frac{R=(100 p m \text { of } 112)}{R \rightarrow(\text { sii) }}=0.30 \cdots$ \\
\hline \multirow{4}{*}{$\begin{array}{l}\text { Standard test } \\
\text { conditions }\end{array}$} & \multicolumn{2}{|c|}{ Test gas conditions } & \multicolumn{2}{|c|}{$\begin{array}{c}\text { Air } \\
\text { at } 20 \pm 2^{\circ} \mathrm{C}, 65 \pm 5 \% \mathrm{RH}\end{array}$} \\
\hline & \multirow{2}{*}{\multicolumn{2}{|c|}{ Circuit conditions }} & $R L=200 \mathrm{ks} 2 \pm 1 \%$ & $R L=10.0 \mathrm{ks} \pm \pm 1 \%$ \\
\hline & & & \multicolumn{2}{|c|}{$V_{C}=7.0 \perp 0.2 V D C, V_{H}=7.0 \perp 0.2 \mathrm{~V} \mathrm{DC}$} \\
\hline & \multicolumn{2}{|c|}{$\begin{array}{l}\text { Conditioning period } \\
\text { vefure lest }\end{array}$} & \multicolumn{2}{|c|}{7 days } \\
\hline
\end{tabular}

Sumber : www.Figaro.com

\section{Mikrokontroler}

Mikrokontroler adalah suatu chip dengan kepadatan yang sangat tinggi, dimana semua bagian yang diperlukan untuk suatu kontroler sudah dikemas dalam satu keping, biasanya terdiri dari CPU (Central Proccesssing Unit), RAM (Random Acess Memory), EEPROM/EPROM/PROM/ROM, I/O, Timer dan lain sebagainya. Rata-rata mikrokontroler memiliki instruksi manipulasi bit, akses ke I/O secara langsung dan mudah, dan proses interupsi yang cepat dan efisien.

Susunan pin mikrokontroler ATMega32 diperlihatkan pada Gambar di bawah ini.

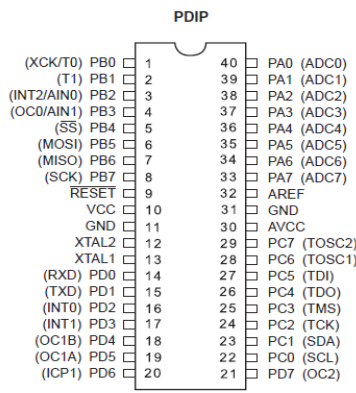

Gambar 4. Konfigurasi Pin ATMega32

\section{Pengatur Informasi Waktu}

Pada Gambar 5. pin RTC DS1307 ialah Pengambilan data yang akan dilakukan memiliki rentang waktu tertentu sesuai dengan pengaturan yang ditentukan. Pengaturan rentang waktu pengambilan data tersebut dapat dilakukan dengan sebuah chip (IC) yang 
sering dikenal dengan Real Time Clock. IC pengendali waktu yang digunakan dalam tugas akhir ini adalah RTC DS1307.

RTC DS1307 memiliki register yang dapat menunjukkan waktu dalam detik, menit, jam, tanggal, bulan dan tahun. RTC ini didesain dengan 128 lokasi RAM yang terdiri dari 15 byte untuk data waktu serta kontrol, dan 113 byte sebagai RAM yang dapat digunakan sebagai RAM pada umumnya. RTC DS 1307 menggunakan bus yang termultipleks sehingga bisa menghemat penggunaan pin pada mikrokontroler.

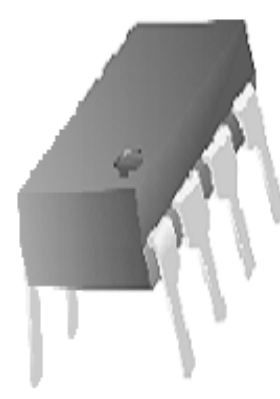

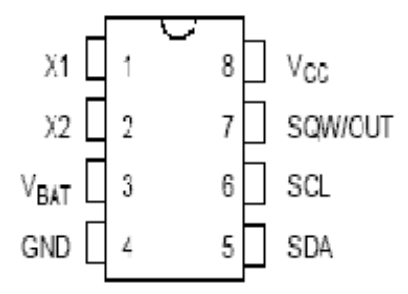

DS1307 8-PIN CIP (300 MIL)

\section{PIN DESCRIPTION}

$V_{C C} \quad-$ Primary Power Supply

$\mathrm{X} 1, \mathrm{X} 2 \quad-32.768 \mathrm{KHz}$ Crystal Connection

$V_{B A T} \quad-+3$ Volt Battery Input

GVD $\quad-$ Ground

SDA - Serial Data

SCL - Serial Clock

SQW/OUT - Square wave/Output Driver

\section{Gambar 5. Pin RTC DS1307}

\section{Memori Eksternal sebagai Penyimpan Data}

Pada gambar 6 Memory MMC eksternal digunakan untuk sarana penyimpanan data pada alat elektronik seperti kamera digital dan handphone dan format data pada MMC umumnya menggunakan FAT. Secure Digital (SD) atau Multi Media Card (MMC) seringkali digunakan sebagai sarana penyimpan data pada Personal Digital Assistant (PDA), kamera digital, dan telepon seluler (ponsel). Beberapa perintah dasar untuk SD Card juga dapat digunakan untuk MMC sehingga kita dapat menggunakan SD atau MMC. Format data pada SD maupun MMC umumnya menggunakan format FAT. FAT12 digunakan untuk kapasitas 16 MB ke bawah. FAT16 digunakan untuk kapasitas $32 \mathrm{MB}$ hingga 2 GB. FAT32. Memori yang akan digunakan dalam alat ini adalah $\mathrm{SD} / \mathrm{MMC}$ memori
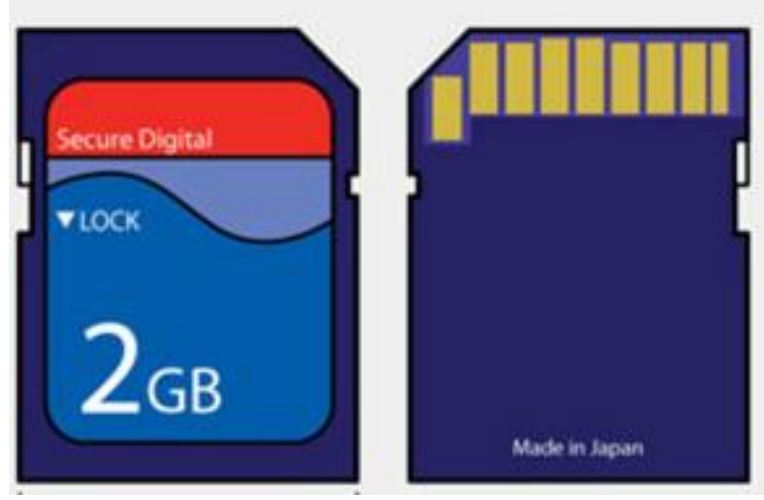

Gambar 6. Memory MMC

\section{Codevision AVR}

Codevision AVR merupakan compiler bahasa $\mathrm{C}$, dengan lingkungan pemograman terpadu dan program generator otomatis didesain khusus untuk mikrokontroler keluarga 
Atmel AVR. Dapat digunakan pada Windows 98, MeNT 4, XP, dan Vista. Fungsi utama Codevision AVR ialah untuk menuliskan program yang akan masuk kedalam mikrokontroler[4].

\section{Perencanaan dan Perancangan Alat}

\section{a. Perancangan Hardwere}

Perancangan hardware system Data logger secara keseluruan memiliki berbagai macam Sistem pendukung seperti: sensor gas TGS 2201, RTC (Real Time Clock), Memori Eksternal dan LCD (liquid crystal display).

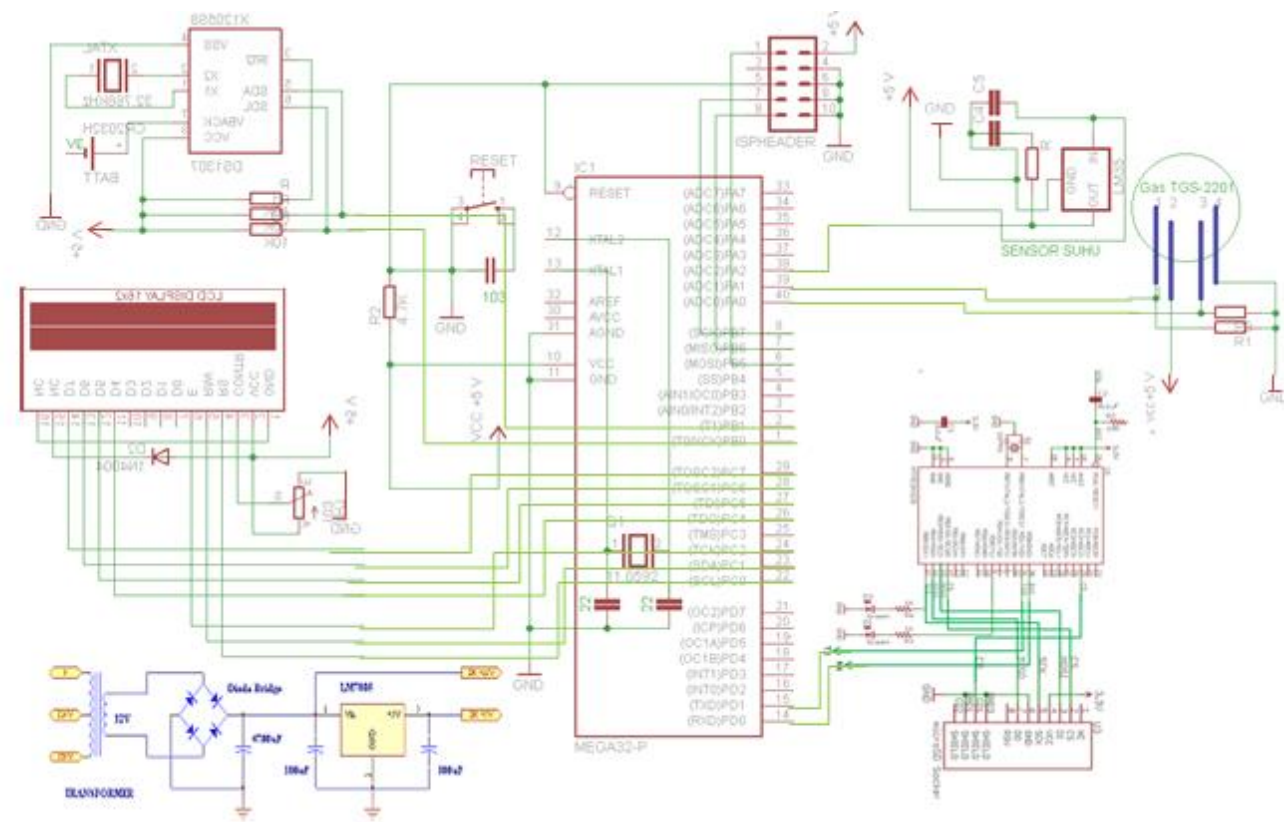

Gambar 7. Tempat Sampah Sebelum dan Sesudah dimodifikasi

Setelah beberapa pengujian sebelumnya yaitu pengujian mikrokontroler AVR ATMega32, pengujian rangkaian LCD, Suhu LM35, RTC DS1307,Sensor Gas TGS2201, dan IC Atmega328 memori, langkah selanjutnya adalah menggabungkan semua pengujian menjadi satu Alat pencatatan dan perekaman gas polutan mengunakan data logger berbasis Mikrokontroler.

satu buah rangkaian Sensor Gas TGS2201dihubungkan pada Port A.0, dan Port A.1 mikrokontroler AVR ATMega32, sedangkan Port A.2 untuk sensor suhu.

Untuk unit display LCD 2x16 diaktifkan melalui Port C dan catu daya 5 V. Pin 1 dan Pin 2 pada LCD terhubung dengan VCC dan GND. Pin 3 LCD $2 \times 16$ berfungsi sebagai kontras sehingga Pin ini diberi VR (variabel resistor) sebesar $10 \mathrm{k} \Omega$ untuk mengatur kontras dengan cara memutar VR sampai didapat kontras yang baik. LCD memiliki tiga jalur kontrol dan jalur data yang berjumlah delapan atau empat bit. Tiga jalur kontrol, RS (Pin 4), RW (Pin 5), E (Pin 6) dihubungkan pada PC.0, PC.1, PC.2 mikrokontroler AVR ATMega32. Karena jalur data yang dipakai adalah 4 bit (DB4, DB5, DB6, DB7) terhubung pada PC.4, PC.5, PC.6, dan PC.7 mikrokontroler AVR 
ATMega32. Untuk menghidupkan backligt, pin 15 terhubung dengan diode yang langsung terhubung ke VCC dan Pin 16 dihubungkan dengan GND.

Satu buah sensor RTC DS1307 akan dipergunakan untuk mencantumkan waktu. Output dari satu rangkaian RTC DS1307 akan dihubungkan dengan Port B (input, PB.2 dan PB.3) mikrokontroler AVR ATMega32.

Rangkaian Memori SD Card yang dihubungkan dengan Port D ( Output PD.0 dan PD.1) mikrokontroler AVR ATMega32 untuk perekaman data.

Setelah semua sudah terhubung dengan baik, program yang sudah dibuat dengan CodeVisionAVR didownload dengan menggunakan downloader AVR 910 USB programer yang terhubung pada port B, yaitu PB.5 (MOSI), PB.6 (MISO), PB7 (SCK) dan pin 9 (RESET). Karena downloader ini menggunakan AVR 910 USB programer, maka programer type pada CodeVisionAVR yang digunakan adalah Atmel AVRProg (AVR910). Setelah setting sudah sesuai kebutuhan, barulah program di masukkan ke mikrokontroler AVR ATMega32.

\section{b. Perancangan Software}

Pada perancangan software system Data logger Berbasis Mikrokontroler ini menggunakan bahasa $\mathrm{C}$ dan CodeVisionAVR sebagai compilernya. Bahasa $\mathrm{C}$ digunakan untuk membuat program ini dibutuhkan untuk mengatur kinerja dari hardware sehingga dapat berjalan sesuai dengan yang diharapkan. Sedangkan CodeVisionAVR pada gambar 8. digunakan sebagai alat bantu pemrograman (programming tool) yang bekerja dalam lingkungan pengembangan perangkat lunak (software) yang terintegrasi (Integrated Development Environment, IDE).

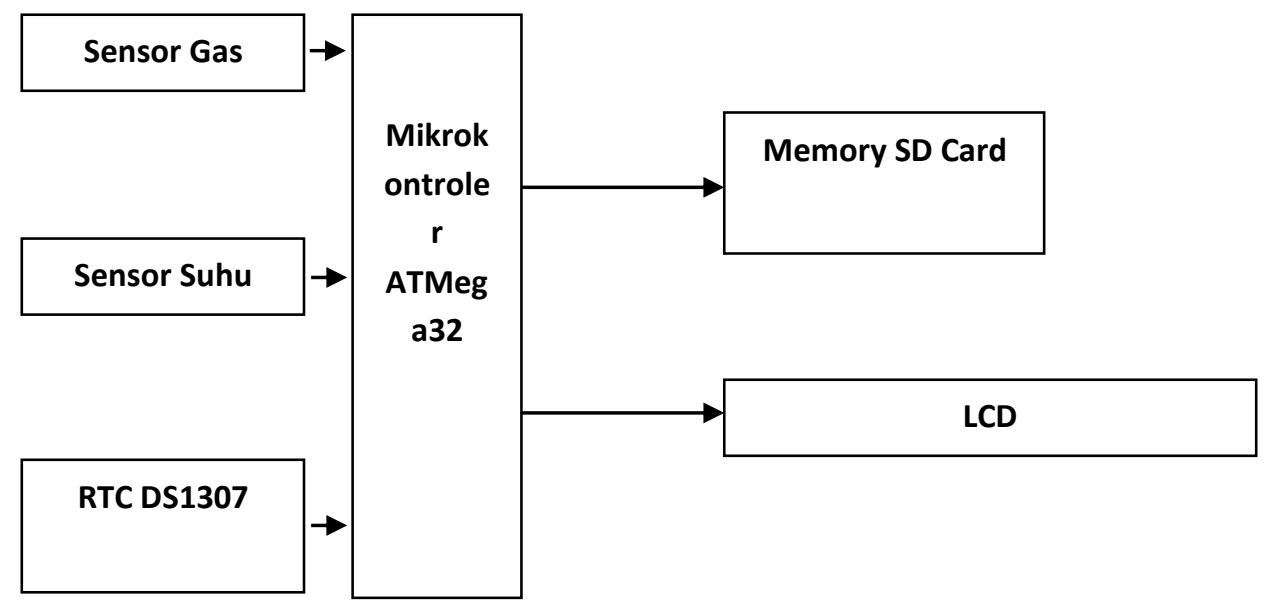

Gambar 8. Blok Diagram Sistem

Keterangan Gambar 8. :

Sensor Gas yang dipakai adalah sensor TGS2201, Sensor tersebut hanya bereaksi ketika terdapat gas buang kendaraan. 
Sensor Suhu yang dipakai adalah sensor Lm35Dz, Sensor tersebut bereaksi untuk mengetahui keadaan suhu pada saat itu juga.

$>$ RTC DS1307 ialah Pengambilan data yang akan dilakukan memiliki rentang waktu tertentu sesuai dengan pengaturan yang ditentukan.

$>$ Mikrokontroler ATMega32 sebagai unit pengelolah data berupa output dan input.

$>$ Memory SD Card digunakan untuk sarana penyimpanan data pada alat elektronik yang berfunsi sebagai penyimpanan data yang di hasilkan senso gas, sensor suhu dan RTC.

LCD sebagai indikator Data Logger.

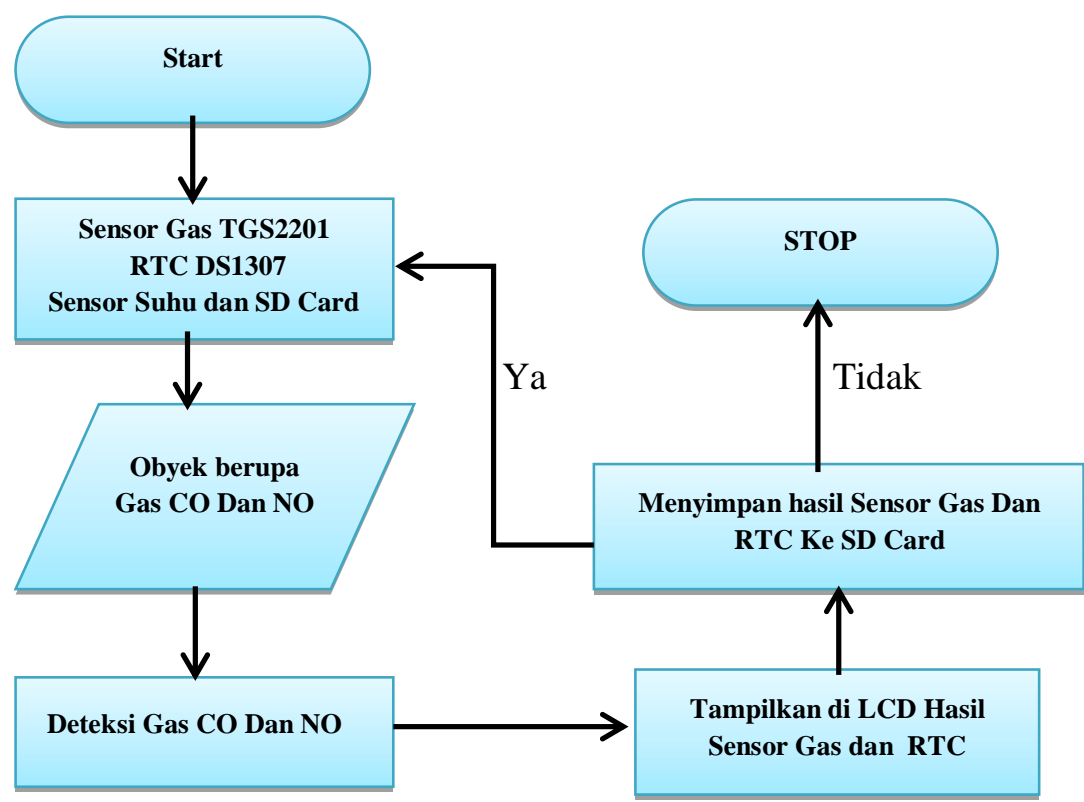

Gambar 9. Flow chart Sistem Keseluruhan

\section{Pengambilan Data dan Analisa}

Dari hasil pengujian pada gambar 7. dapat dilihat rangkaian Sensor Gas TGS2201 dapat bekerja sesuai dengan desain yang di inginkan sehingga dapat disimpulkan bahwasannya rangkaian Sensor Gas TGS2201 dalam kondisi baik. hasil pengujian dari Sensor Gas TGS2201 Yang dimana sudah diatur berdasarkan keputusan badan pengendalian dampak lingkungan (Bapedal) Nomor KEP-107/kabapedal/11/1997. udara sebagai acuan baik buruknya udara sebagai berikut:

Tabel 7. Hasil Pengujian Rangkaian Sensor Gas TGS2201 


\begin{tabular}{|c|c|c|c|c|c|c|}
\hline \multirow[b]{2}{*}{ No } & \multirow[b]{2}{*}{ Kendaraan } & \multirow[b]{2}{*}{ Tahun } & \multirow[b]{2}{*}{ Bahan Bakar } & \multicolumn{2}{|c|}{ Alat deteksi Gas } & \multirow[b]{2}{*}{ Keterangan } \\
\hline & & & & $\begin{array}{c}\text { Gas CO } \\
\mathrm{ppm}\end{array}$ & $\begin{array}{c}\text { Gas NO } \\
\mathrm{ppm}\end{array}$ & \\
\hline 1 & Yamaha Mio & 2011 & Bensin & 70 & 0 & Sedang \\
\hline 2 & Suzuki Nex & 2011 & Bensin & 110 & 0 & Tidak Sehat \\
\hline 3 & Honda Beat & 2011 & Bensin & 50 & 0 & Baik \\
\hline 4 & Toyota Kijang G 2.5 & 2010 & Solar & 0 & 1,3 & Sedang \\
\hline 5 & Isuzu Elf & 2010 & Solar & 0 & 1,8 & Sedang \\
\hline 6 & Mitsubishi L300 & 2010 & Solar & 0 & 1,8 & Sedang \\
\hline
\end{tabular}

Pengukuran ppm dari 10 ppm sampai dengan 1000 ppm, Tegangan referensi yang akan digunakan sebesar $5 \mathrm{~V}$. Jika input ADC bernilai $5 \mathrm{~V}$ maka akan setara dengan nilai 1000 ppm. $(X=$ kenaikan PPM per 1 bitnya adalah sebesar $)$ $\mathrm{X}=$ range/total bit $=\frac{1000}{1024}=0.9765625$

Konversi $\mathrm{ADC}=[(\mathrm{Vin} / \mathrm{Vref}) * 1024]$

Ketika sensor tidak terdapat gas maka tegangan Vin $=0,05 \mathrm{~V}$, maka untuk mengkonversinya ke PPM :

$\mathrm{PPM}=\mathrm{X} *$ Konversi ADC

$=0.9765625 *[(\mathrm{Vin} / \mathrm{Vref}) * 1024]$

$=0.9765625 *[(0,05 / 5) * 1024]$

$=0.9765625 * 10.24$

$=10 \mathrm{ppm}$

* Ketika tegangan Vin $=0.35 \mathrm{~V}$, maka untuk mengkonversinya ke PPM :

$\mathrm{PPM}=\mathrm{X} *$ Konversi ADC

$=0.9765625 *[(\mathrm{Vin} / \mathrm{Vref}) * 1024]$

$=0.9765625 *[(0,35 / 5) * 1024]$

$=0.9765625 * 71.68$

$=70 \mathrm{ppm}$

* Ketika tegangan Vin $=0.55 \mathrm{~V}$, maka untuk mengkonversinya ke PPM :

$\mathrm{PPM}=\mathrm{X} *$ Konversi ADC

$=0.9765625 *[(\mathrm{Vin} / \mathrm{Vref}) * 1024]$

$=0.9765625 *[(0.55 / 5) * 1024]$

$=0.9765625 * 112.64$

$=110 \mathrm{ppm}$

- Ketika tegangan Vin $=0.25 \mathrm{~V}$, maka untuk mengkonversinya ke PPM :

$\mathrm{PPM}=\mathrm{X} *$ Konversi ADC

$=0.9765625 *[(\mathrm{Vin} / \mathrm{Vref}) * 1024]$

$=0.9765625 *[(0.25 / 5) * 1024]$

$=0.9765625 * 51.2$

$=50 \mathrm{ppm}$

Pengukuran ppm dari $0.1 \mathrm{ppm}$ sampai dengan $10 \mathrm{ppm}$, Tegangan referensi yang akan digunakan sebesar 5V. Jika input ADC bernilai 5V maka akan setara dengan nilai 10 ppm.(X = kenaikan PPM per 1 bitnya adalah sebesar)

$$
\begin{gathered}
\mathrm{X}=\text { range } / \text { total } \text { bit }=\frac{10}{1024}=0.009765625 \\
\text { Konversi ADC }=[(\text { Vin } / \text { Vref }) * 1024]
\end{gathered}
$$


* Ketika sensor tidak terdapat gas maka tegangan Vin $=0.05 \mathrm{~V}$, maka untuk mengkonversinya ke PPM :

$\mathrm{PPM}=\mathrm{X} *$ Konversi ADC

$=0.009765625 *[($ Vin $/$ Vref $) * 1024]$

$=0.009765625 *[(0.05 / 5) * 1024]$

$=0.009765625 * 10.24$

$=0.1 \mathrm{ppm}$

* Ketika tegangan Vin $=0.7 \mathrm{~V}$, maka untuk mengkonversinya ke PPM :

$\mathrm{PPM}=\mathrm{X} *$ Konversi ADC

$=0.009765625 *[($ Vin $/$ Vref $) * 1024]$

$=0.009765625 *[(0.7 / 5) * 1024]$

$=0.009765625 * 143$

$=1.3 \mathrm{ppm}$

- Ketika tegangan Vin $=0.9 \mathrm{~V}$, maka untuk mengkonversinya ke PPM :

$\mathrm{PPM}=\mathrm{X} *$ Konversi ADC

$=0.009765625 *[($ Vin $/$ Vref $) * 1024]$

$=0.009765625 *[(0.9 / 5) * 1024]$

$=0.009765625 * 184$

$=1.8 \mathrm{ppm}$

- Ketika tegangan Vin $=0.9 \mathrm{~V}$, maka untuk mengkonversinya ke PPM :

$\mathrm{PPM}=\mathrm{X} *$ Konversi ADC

$=0.009765625 *[($ Vin $/$ Vref $) * 1024]$

$=0.009765625 *[(0.9 / 5) * 1024]$

$=0.009765625 * 184$

$=1.8 \mathrm{ppm}$

Tabel 5.7. Hasil Penyimpanan ke memori SD card

\begin{tabular}{|c|c|c|c|}
\hline JAM & TANGGAL & GAS (CO) Ppm & GAS (NO) Ppm \\
\hline $07: 34: 00$ & $13-01-16$ & 0 & 1,3 \\
\hline $07: 35: 12$ & $18-01-16$ & 0 & 1,8 \\
\hline $07: 46: 38$ & $18-01-16$ & 0 & 1,8 \\
\hline $07: 40: 00$ & $20-01-16$ & 70 & 0 \\
\hline $07: 45: 00$ & $25-01-16$ & 110 & 0 \\
\hline $07: 47: 20$ & $29-01-16$ & 50 & 0 \\
\hline $07: 48: 00$ & $29-01-16$ & 50 & 0 \\
\hline
\end{tabular}

Dalam tabel 5.7 merupakan data penyimpanan sistem data logger yang di lakukan didekat kenalpot mengunakan jarak $5 \mathrm{~cm}$ dan suhu $21{ }^{\circ} \mathrm{C}$. Pada waktu 07:34:00 dan tanggal 13-01-16 dilakukan pengujian pada kendaraan yang berbahan bakar solar sehingga terdeteksi nilai gas NO 1,3 Ppm. Pada hari berikutnya tanggal 18-01-16 jam 07:35:00 dilakukan pengujian lagi pada kendaraan berbahan bakar solar dengan tipe yang berbeda sehingga terdeteksi nilai gas NO 1,8 Ppm, begitu juga pengujian-pengujian berikutnya dengan bahan bakar solar akan terdapat nilai gas NO (Nitrogen Monoksida). Sedangkan nilai CO (Carbon Monoksida) tidak terdeteksi karena bahan bakar solar tidak mempunyai kadar gas CO (Carbon Monoksida) begitu juga sebaliknya. 
Selanjutnya pada tanggal 20-01-16 jam 07:40:00 dilakukan pengujian terhadap kendaraan yang berbahan bakar bensin sehingga terdeteksi nilai gas CO $70 \mathrm{Ppm}$. Pada tanggal 25-01-16 jam 07:45:00 pengujian di lakukan dengan tipe kendaraan yang berbeda di mana terdapat nilai gas CO $110 \mathrm{Ppm}$. Setelah itu nilai yang sudah di hasilkan oleh sensor di simpan ke dalam memori SD card melalui data logger yang dapat di lihat melalui computer dengan mengunakan card reader.

\section{Kesimpulan dan Saran}

\section{a. Kesimpulan}

Berdasarkan hasil penelitian yang dilakukan dapat diambil kesimpulan sebagai berikut :

Mikrokontroler AVR ATMega 32 mampu berfungsi sebagai pengendali utama (central processing unit) yang mengendalikan proses dari sistem Data Logger CO dan NO Berbasis Mikrokontroler. Semua proses dapat dikendalikan dengan baik, mulai dari pembacaan sensor gas, sensor RTC (Real Time Clock), IC Atmega328 memori SD Card serta penampilan status pada LCD $2 \times 16$. Sistem data logger yang dirancang berguna menyimpan data sensor RTC (Real Time Clock) dan sensor Gas TGS2201 sebagai tolak ukur gas yang akan datang. Dimana kapasitas memori SD Card 8GB, sebagai penyimpan data $50 \mathrm{~KB}$ perhari, interval pengambilan data 1 menit sekali yang dapat digunakan selama 120 hari.

Berdasarkan penelitian yang dilakukan terdapat jeddah waktu proses penyimpanan data selama 30 menit kemudian kembali melakukan penyimpanan data selama 30 menit.

\section{b. Saran}

Pada penelitian ini memiliki banyak kekurangan sehingga dimungkinkan untuk pengembangan lebih lanjut. Oleh karenanya penulis merasa perlu untuk memberi saran bahwa pengembangan system Data logger terdapat biodata kendaraan yang di uji.

\section{Daftar Pustaka}

[1] Bejo, Agus.2012. C \& AVR Rahasia kemudahan Bahasa C dalam Mikrokontroller ATMega8535. Yogyakarta: Graha Ilmu.

[2] Crosby.G.D. Wichaksana, 2007, Environment Toxicology And Chemistry. Resource Management, National Atmospheric, Silver Spring, MD.45PP, 1998.

[3] Dirjen Perhubungan Darat, 2008, Program Langit Biru dan Konservasi Energi (Jurnal).

[4] Daryanto, 2012. Teknik Dasar Elektronika Komunikasi. Bandung: PT. Sarana Tutorial Nurani Sejahtera.

[5] Datasheet.2004.DS1307,(Online), (http://www.maximic.com/quick_view2.cfm/qv_pk/2685, Diakses tanggal 7 April 2014. 
[6] Figaro, \& Engineering. (2008). Technical Information For TGS 2201.

[7] Hilmi Yulianto. Membuat alat ukur emisi gas buang kendaraan bermotor CO dan NO berbasis mikrokontroler ATMega8535,2013.

[8] Manahan. Stanley E. Environmental Chemistry Sixth Edition. London: Lewis Publisher CRC Pres. Inc, 1994. Agusnar, 2005 Pencemaran Udara

[9] Nugroho Amien.Ensiklopedia Otomotif. Jakarta: Gramedia Pustaka Utama, 1996.

[10] Slovin dikutip dari Andang. Sistem Data Logger Curah Hujan Dengan Model Tipping

Bucket Berbasis Mikrokontroller, Yogyakarta : Alfabeta $p$ : 160-166, 2011.

[11] http:// elmchan.org/docs/mmc/mmc. SD/MMC. Diakses tanggal 12 Agustus 2015

[12] http://www.atmel.com/atmega16. Diakses tanggal 7 April 2015

[13] http:// www.datasheet catalog.com /LCD 16x2 data sheet. Diakses tanggal 7 April 2015.

[14]htpp://tech.blogspot.com/2009/11/tgs-2201-sensor gas olinpembuangan. Diakses tanggal 9 Oktober 2015

[15] htpp://www.cetsuii.org/BML/Udara/ISPU/ISPU\%20(Indeks\%20Standar\%20

Pencemar\%20Udara).htm keputusan badan pengendalian dampak lingkungan (Bapedal) Nomor KEP-107/kabapedal/11/1997

\section{Biodata Pribadi}

1. Nama lengkap : Muhammad Sahri

2. Tempat/ tanggal lahir: Gresik, 27 September 1990

3. Jenis kelamin : Laki-laki

4. Kewarganegaraan : Indonesia

5. Tinggi, Berat Badan : $170 \mathrm{~cm}, 65 \mathrm{~kg}$

6. Agama : Islam

7. Status

: Belum menikah

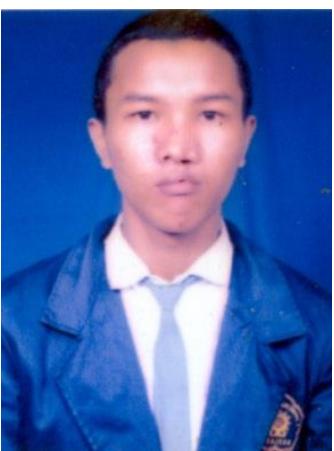

8. Alamat

: Kedung Kakap, RT 03 / RW 02, Kedung Sekar

Kecamatan Benjeng, Kab Gresik, Jawa Timur

9. No. Telp

: 085632443877

10. Email

: Msyahri75@yahoo.co.id

\section{B. Riwayat Pendidikan}

1. TK

2. MI

3. MTS

4. SMK

: TK Dharma Wanita Klampok 1994-1996

: SDN Kedung Sekar 1996-2002

5. Perguruan Tinggi

: SMP Muhammadiyah 8 Benjeng 2002-2005

: SMK Muhammadiya 2 Gresik 2005-2008

: Universitas Muhammadiyah Gresik,

Program Studi Teknik Elektro S1 2009-2016 